\author{
Robert FULARSKI ${ }^{1}$ \\ Kamil OCHA ${ }^{2}$ \\ Ryszard FILIP ${ }^{3}$
}

\title{
WPLYW PRZYGOTOWANIA POWIERZCHNI KOLA ZĘBATEGO NA WARTOŚĆ NAPRĘŻEŃ WŁASNYCH OKREŚLANYCH METODĄ DYFRAKCJI RENTGENOWSKIEJ
}

\begin{abstract}
Koła zębate przekładni lotniczych cechuje wysoki współczynnik niezawodności, wymagany ze względu na obszar zastosowania, dynamiczny charakter pracy oraz przenoszoną moc. Podczas całego cyklu eksploatacyjnego powierzchnie boczne zębów oraz obszary ich podstaw są narażone na uszkodzenia związane z różnymi stanami naprężeń występującymi w czasie zazębienia oraz okresie, kiedy poszczególne zęby kół współpracujących nie stykają się ze sobą. Koncentracja tych naprężeń, związana m.in. z dokładnością wykonania zębów, może prowadzić do różnego typu defektów, takich jak: ,pitting”, zgniot, złom, uszkodzenia interferencyjne, wytarcia, wydarcia, odpryski, zatarcia czy przegrzania. W związku z tym koła zębate są poddawane m.in. badaniom naprężeń własnych metodą dyfrakcji rentgenowskiej, dla której procedura wykonania pomiarów oraz przygotowania materiału badawczego jest problematyczna ze względu na ograniczony lub niemożliwy bezpośredni dostęp do wymaganych obszarów pomiarowych. W niniejszym artykule opisano dwie metody przygotowania próbek do badań naprężeń własnych $\mathrm{z}$ zastosowaniem dyfraktometru rentgenowskiego wyposażonego w lampę chromową. Zakresem badań objęto: polerowanie elektrolityczne oraz cięcie elektroerozyjne. Przygotowane próbki kół zębatych, reprezentujące rozważane metody, poddano serii pomiarów na stanowisku badawczym, a otrzymane wartości naprężeń, reprezentujące ich stany w warstwie wierzchniej, poddano analizie. Porównano wpływ obydwu metod przygotowania kół zębatych na wartość naprężeń własnych warstwy wierzchniej zębów koła zębatego oraz wykazano, że rodzaj obróbki stosowanej podczas przygotowania próbek ma wpływ na wartości pomiarów naprężeń własnych.
\end{abstract}

Słowa kluczowe: dyfrakcja rentgenowska, naprężenia własne, koła zębate, polerowanie elektrolityczne, cięcie elektroerozyjne, warstwa wierzchnia

1 Autor do korespondencji: Robert Fularski, Pratt \& Whitney Rzeszów S.A., ul. Hetmańska 120, 35-078 Rzeszów, e-mail: robert.fularski@ prattwhitney.com, ORCID: 0000-0001-9994-2601.

${ }^{2}$ Kamil Ochał, Politechnika Rzeszowska im. Ignacego Łukasiewicza, al. Powstańców Warszawy 12, 35-959 Rzeszów.

${ }^{3}$ Ryszard Filip, Politechnika Rzeszowska im. Ignacego Łukasiewicza, al. Powstańców Warszawy 12, 35-959 Rzeszów. 


\section{Wprowadzenie}

Współczesny rozwój lotnictwa jest związany w dużej mierze z czynnikami ekonomicznymi, pozwalającymi liniom lotniczym obniżać koszty eksploatacyjne. Działania konstruktorów wynikające $\mathrm{z}$ tych potrzeb przekładają się na redukcję masy płatowców, a co się z tym wiąże ich poszczególnych modułów i komponentów. Możliwości takie stwarzają materiały nowej generacji, z których powstają części konstruowane $\mathrm{z}$ użyciem oprogramowania do komputerowego wspomagania projektowania CAD (Computer Aided Design) i MES (Metoda Elementów Skończonych, ang. Finite Element Method, FEM). W wielu przypadkach nowo opracowywane komponenty, w związku z potrzebą redukcji masy, są narażone na zwiększone obciążenia. Przykładem mogą być kolejne konstrukcje rozwojowe silników stosowanych w lotnictwie, których osiągi rosną, pomimo obniżenia ich masy całkowitej. Działania z tym związane pozwalają przewoźnikom zwiększyć liczbę pasażerów lub masę przewożonych towarów.

Minimalizacja gabarytów oraz masy modułów przekładniowych, stosowana w przemyśle lotniczym, przekłada się na ilość materiału niezbędną do ich wytworzenia, a co za tym idzie redukcję wspomnianych wcześniej kosztów części składowych oraz rosnące obciążenia, jakie przenoszą współcześnie konstruowane wyroby [1]. Przykładem takich komponentów są koła zębate przekładni lotniczych, pracujące $\mathrm{w}$ warunkach szczególnie dużych obciążeń. Stawiane są im specjalne, wysokie wymagania wytrzymałościowe, zapewniające niezawodność mechanizmów przekładniowych oraz oczekiwaną liczbę cykli pracy przy jednoczesnej minimalizacji liczby operacji serwisowych, związanych z weryfikacją ich stanu technicznego podczas całego okresu eksploatacji.

Koła zębate, a w szczególności ich zęby, są narażone na różnego typu uszkodzenia, wynikające m.in. z dynamicznego charakteru pracy. Przekłada się to na oczekiwaną, wysoką wytrzymałość zmęczeniową [2]. Czynniki takie jak np. naciski punktowe powodują wzrost naprężeń miejscowych, które mogą skutkować wystąpieniem defektów. Niektóre z nich, jak chociażby pitting czy przegrzanie, są związane $\mathrm{z}$ olejem. W pierwszym przypadku jest on przyczyną powstawania i propagacji pęknięć, natomiast w drugim, w wyniku wystąpienia nieciągłości filmu olejowego występuje wzrost oporów tarcia, a co za tym idzie temperatury powierzchni bocznej zębów. Temperatura pracy kół zębatych w przekładni lotniczej osiąga wartość bliską niezbędnej do inicjacji przemian fazowych towarzyszących procesowi odpuszczania. Wystąpienie przemian fazowych podczas eksploatacji koła zębatego powoduje niestety utratę jego właściwości użytkowych. Ze względu na konieczność zahamowania procesów zachodzących podczas odpuszczania, skutkujących zmniejszeniem twardości warstwy przypowierzchniowej zębów, gatunki stali, z których są wykonywane koła zębate, zawierają w swoim składzie dodatki pierwiastków stopowych, np. Cr, Mo.

Coraz częściej stosowanym materiałem do wyrobu kół zębatych przekładni lotniczych jest stal stopowa Pyrowear 53 (AMS6308) [3] o składzie chemicz- 
nym: $\mathrm{C}-0,11 \%, \mathrm{Mn}-0,4 \%, \mathrm{Si}-0,9 \%, \mathrm{Cr}-1,0 \%, \mathrm{Ni}-2,0 \%, \mathrm{Mo}-3,25 \%$, $\mathrm{Cu}-2,0 \%, \mathrm{~V}-0,1 \%, \mathrm{Fe}-$ reszta [4]. Zainteresowanie tą stalą rośnie ze względu na podwyższony do temperatury ok. $240^{\circ} \mathrm{C}$ próg inicjacji procesu odpuszczania. Stal ta w procesach technologicznych, mających na celu wytworzenie koła zębatego, jest poddawana procesom obróbki cieplnej oraz mechanicznej, w celu nadania wymaganych właściwości użytkowych stanu warstwy wierzchniej, w tym: ściskających naprężeń własnych, mikrostruktury i topografii powierzchni $[5,6]$.

Ustalono, że jednym z czynników wpływających na wytrzymałość zmęczeniową zębów koła zębatego jest stan naprężeń własnych, którego wymagane wartości określają normy lotnicze [1-3, 5-12]. W celu zapewnienia ich wymaganego poziomu konieczne jest stosowanie określonych procesów obróbkowych $[3,7,8]$, których przykładem może być proces obróbki ściernej - szlifowanie. Umożliwiają one wytworzenie naprężeń ściskających w warstwie wierzchniej, przy czym wymagane jest zastosowanie wysokiego reżimu technologicznego kontroli parametrów technicznych obróbki tych procesów (m.in.: prędkości skrawania, posuwu), pozwalającego na zachowanie ich wielkości w wymaganym zakresie.

Ze względu na rodzaj oczekiwane są naprężenia ściskające. Wpływają one korzystnie na właściwości eksploatacyjne części - hamują inicjację i propagację pęknięć w warstwie wierzchniej, będących w wielu przypadkach przyczyną poważnych uszkodzeń określonych podzespołów lub całych zespołów [8, 9-12]. W przekładniach lotniczych uszkodzenia takie przekładają się na bezpośrednie zagrożenie bezpieczeństwa lotu. Koła zębate, zwłaszcza te stosowane w przemyśle lotniczym, muszą cechować się wysoką niezawodnością, stąd istotna jest weryfikacja stanu i charakteru naprężeń własnych w warstwie wierzchniej [8].

Analizę stanu naprężeń własnych prowadzi się w charakterystycznych dla koła zębatego obszarach, jakimi są powierzchnia boku zęba w obrębie koła podziałowego oraz stopa zęba (ze względu na uciążliwość przygotowania materiału badawczego, często weryfikowane w dnie wrębu). Obszary te charakteryzują się największymi obciążeniami związanymi z przekazywaniem mocy przez współpracujące, będące w zazębieniu koła zębate. Na podstawie dostępnych wyników pomiarów naprężeń własnych stwierdzono, że duży wpływ na otrzymywane wyniki pomiarów wywiera sposób przygotowania próbki do badań metodą dyfrakcji rentgenowskiej.

Głównymi procesami stosowanymi w przygotowaniu materiału do badań metodą dyfrakcji rentgenowskiej są: obróbka skrawaniem, np. frezowanie, wycinanie metodą elektroerozyjną lub cięcie strumieniem wody. Tego typu obróbki są w stanie powodować zmiany stanu naprężeń własnych badanej próbki, stąd otrzymywane wartości wielkości pomiarowych mogą być nieadekwatne do stanu rzeczywistego. Problemy wynikają z trudności przewidzenia, w jakim stopniu metoda stosowana do przygotowania próbki wpłynie na zmianę wartości naprężeń własnych, zwłaszcza w przypadku badania ich stanu w obszarze stopy zęba. W celu wykonania badania w tym rejonie niejednokrotnie niezbędne staje się 
usunięcie całych zębów uniemożliwiających przeprowadzenie procedury pomiarowej charakterystycznych, określonych obszarów.

W pracy przeprowadzono badania weryfikujące wpływ dwóch metod przygotowania powierzchni kół zębatych na uzyskane wartości naprężeń własnych w wyznaczonych obszarach.

\section{Materiał i metodyka badań}

Badania przeprowadzono na kole zębatym daszkowym, wykonanym z ulepszonej cieplnie stali stopowej Pyrowear 53 o zawartości pierwiastków stopowych przedstawionej w tab. 1. Procedurę pomiarową przeprowadzono przy zastosowaniu dyfraktometru Proto iXRD firmy Proto Manufacturing (rys. 1.). Do określenia stanu naprężeń własnych warstwy wierzchniej, badanego dwuwieńcowego koła zębatego o zębach skośnych, zastosowano metodę dyfrakcji rentgenowskiej $\sin ^{2} \psi$. W prowadzonych badaniach stosowano promieniowanie charakterystyczne lampy chromowej $\mathrm{CrK}_{\alpha}$ o średnicy wiązki $1 \mathrm{~mm}$. Napięcie anodowe i prąd anodowy wynosity odpowiednio $20 \mathrm{kV}$ i $4 \mathrm{~mA}$.
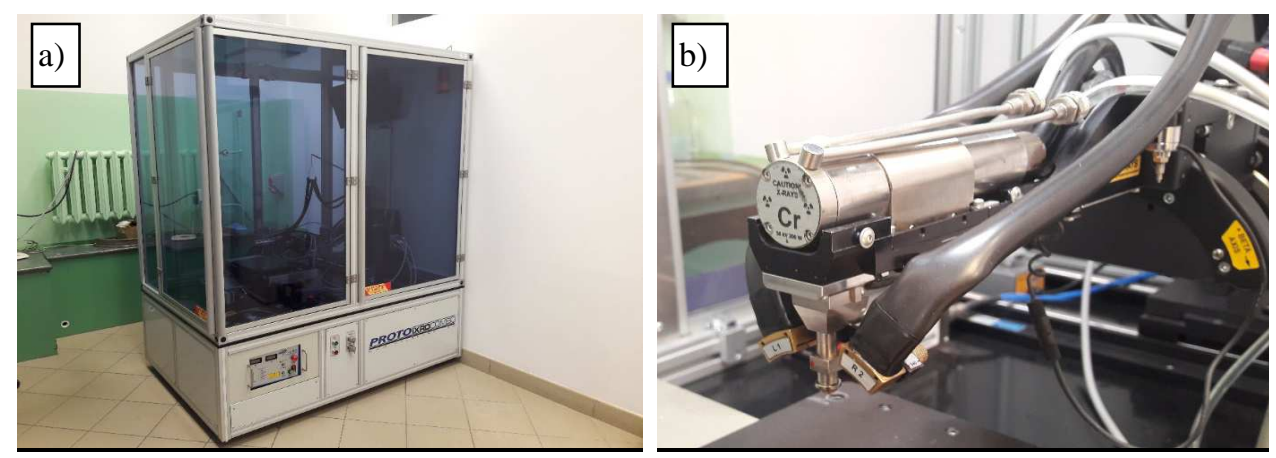

Rys. 1. Stanowisko badawcze - dyfraktometr Proto iXRD firmy Proto Manufacturing (a), lampa rentgenowska (b)

Analizę stanu naprężeń własnych prowadzono na powierzchni bocznej zęba, w obszarze koła tocznego (średnicy podziałowej) oraz stopy zęba w rejonie dna wrębu. Pomiary prowadzono w połowie szerokości wieńca zębatego. Naprężenia określono w dwóch kierunkach (rys. 2.) na zadanych głębokościach od powierzchni bocznej zęba i dna wrębu, określonych w obowiązującej dla badanych kół normie, stosowanej do zatwierdzania kół zębatych dla lotnictwa - jednakowych dla obydwu obszarów. Wymagane dla kół zębatych wielkości naprężeń własnych warstwy wierzchniej wynikają z obliczeń inżynierskich dopuszczalnych naprężeń stykowych, których wielkości są określone w normach branżowych stosowanych w przemyśle lotniczym. Reprezentantem tych norm jest np. ANSI/AGMA 2001 - D04 [13]. Obszary badawcze natomiast zawierały się w przedziale $\pm 3 \mathrm{~mm}$ od wskazanych na rys. 2. punktów określających średnicę 
koła podziałowego i stopy zęba, wzdłuż profilu wyznaczonego przez krzywą powstałą w wyniku przecięcia powierzchni bocznej zęba płaszczyzną do niej prostopadłą, przechodzącą przez punkt symetrii linii zęba oraz w odległości $\pm 3 \mathrm{~mm}$ od rozpatrywanej płaszczyzny.

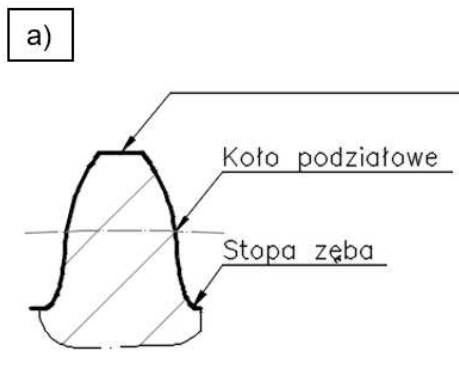

c) b)

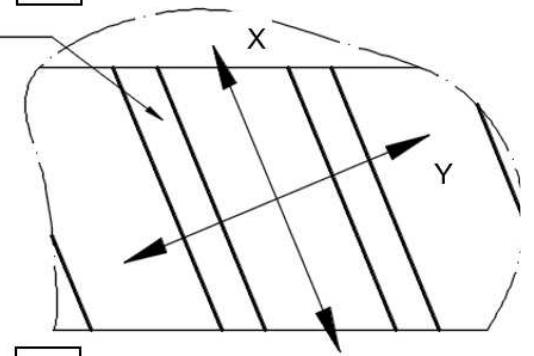

d)

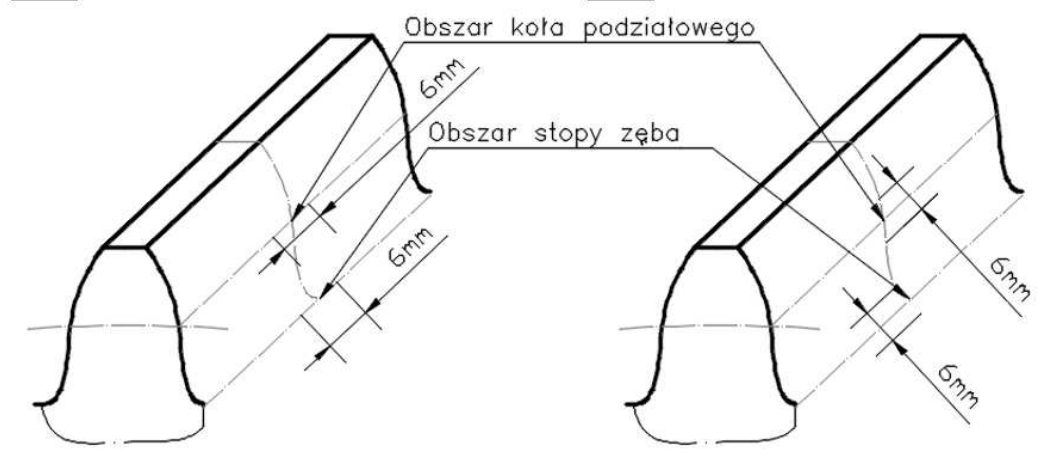

Rys. 2. Lokalizacja obszarów wykonywania pomiarów naprężeń normalnych бx oraz бy (a, c, d), kierunki pomiarów X oraz Y (b)

W badaniach zastosowano stałą elastyczności promieniowania rentgenowskiego: $1+E / \vartheta$, gdzie: E - moduł Younga, $\vartheta$ - współczynnik Poissona [14-16]. Stała ta dla materiału PYROWEAR 53 wynosi 25000 ksi (172369MPa). Wartość kąta Bragga $2 \theta=156^{\circ}$.

Tabela 1. Zawartość pierwiastków stopowych stali PYROWEAR 53 [4]

\begin{tabular}{|c|c|c|c|c|c|c|c|c|}
\hline $\mathrm{Cr}$ & $\mathrm{Ni}$ & $\mathrm{C}$ & $\mathrm{Mo}$ & $\mathrm{Cu}$ & $\mathrm{V}$ & $\mathrm{Mn}$ & $\mathrm{Si}$ & $\mathrm{Fe}$ \\
\hline 1,0 & 2,0 & 0,11 & 3,25 & 2,0 & 0,1 & 0,4 & 0,9 & reszta \\
\hline
\end{tabular}

Przyjęto dwie metody przygotowania powierzchni koła: polerowanie elektrolityczne oraz wycinanie elektroerozyjne. Przygotowanie powierzchni obejmowało usunięcie fragmentów lub kilku zębów (w zależności od metody), które 
zasłaniały obszar oddziaływania wiązki promieniowania rentgenowskiego, uniemożliwiając wykonanie dyfraktogramu.

Przygotowanie materiału do części badań określających wielkości naprężeń własnych z zastosowaniem metody polerowania elektrolitycznego wykonano przy użyciu polerki elektrolitycznej 8818-V3 firmy Proto Manufacturing. W procesie polerowania zastosowano elektrolit A2 firmy Struers, zawierający metanol oraz kwas nadchlorowy.

Chcąc zabezpieczyć pozostałe powierzchnie zębów przed oddziaływaniem elektrolitu, przygotowano specjalną formę silikonową (rys. 3.). W celu dodatkowej ochrony powierzchni zębów zabezpieczono je lakierem akrylowym, który usunięto acetonem po zakończeniu operacji polerowania.
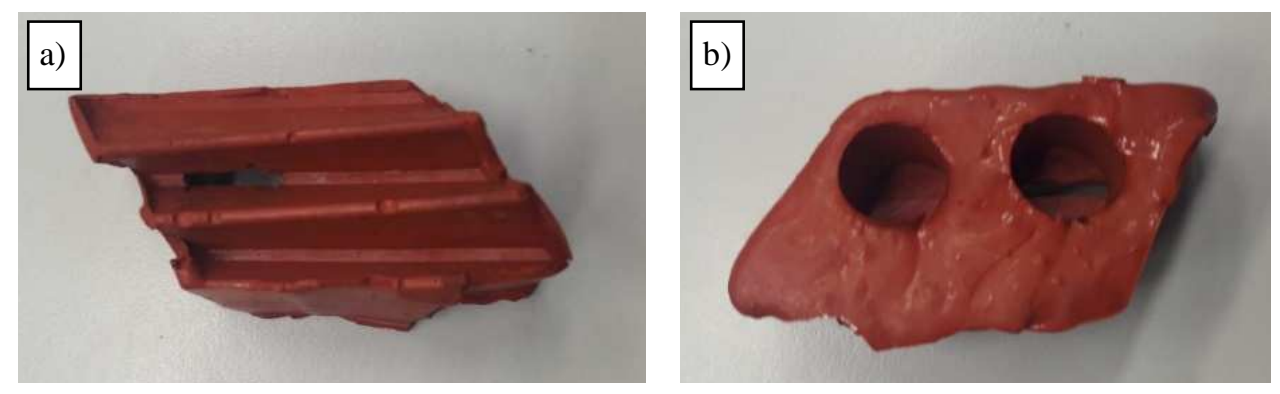

Rys. 3. Forma silikonowa zastosowana w procesie polerowania elektrolitycznego koła zębatego (a), otwory umożliwiające zamontowanie pistoletu polerki elektrolitycznej (b)

Po zakończeniu polerowania mającego na celu usunięcie obszarów zębów uniemożliwiających wykonanie pomiaru, w środkowej części wieńca koła zębatego powstał krater (rys. 4. i 5.). Tak przygotowana próbka umożliwiła wykonanie pomiaru naprężeń własnych w kierunku prostopadłym do wyznaczonego przez linię zęba.

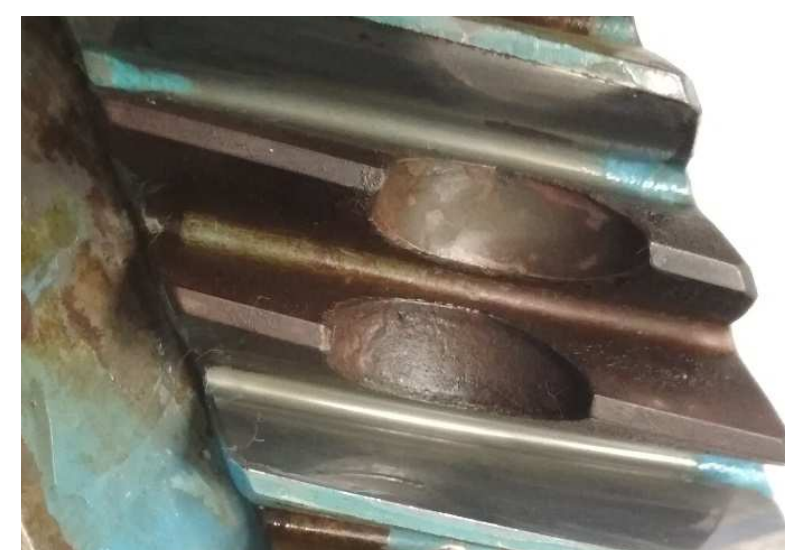

Rys. 4. Koło zębate po procesie polerowania elektrolitycznego efekt końcowy 


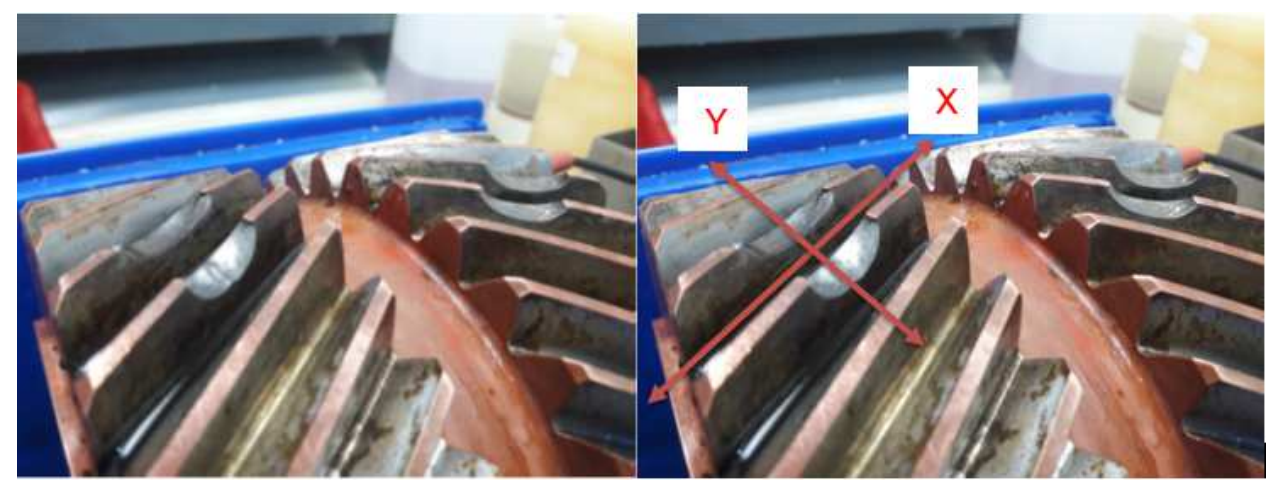

Rys. 5. Efekt końcowy polerowania elektrolitycznego uzębienia koła zębatego z zaznaczonymi kierunkami badań

Drugą metodą przygotowania próbki do badań naprężeń własnych było cięcie elektroerozyjne. Materiał badawczy (rys. 6.) poddano procesom przygotowawczym na 4-osiowej wycinarce elektroerozyjnej BP05d firmy ZAP B.P. Powierzchnię, na której wykonano pomiary naprężeń własnych, zabezpieczono lakierem akrylowym. Jako efekt końcowy uzyskano powierzchnie powstałe w wyniku wycięcia kilku zębów koła na wysokości ok. $2 \mathrm{~mm}$ od dna wrębu, pozwalające na pomiary stanu naprężeń w obszarze stopy zęba. Ponadto odsłonięto powierzchnie boczne zębów w celu pomiaru naprężeń własnych zlokalizowanych w rejonie koła podziałowego (rys. 6.).

Rys. 6. Efekt końcowy cięcia elektroerozyjnego z oznaczonymi kierunkami badań

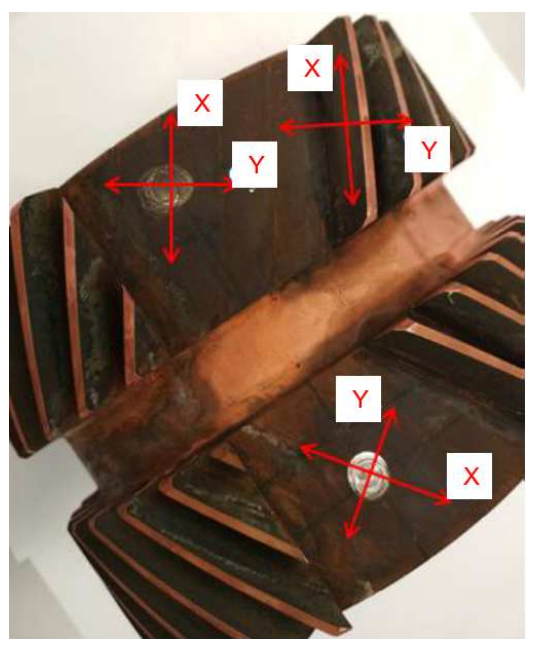

\section{Wyniki badań oraz ich analiza}

Wartość naprężeń własnych określono w wyznaczonych punktach pomiarowych (rys. 1.), kół zębatych daszkowych (rys. 5. i 6.). Naprężenia normalne $\sigma_{x}$ 
i $\sigma_{\mathrm{y}}$ badano w każdym punkcie pomiarowym w dwóch prostopadłych kierunkach: $\mathrm{X}$ oraz Y. W wyniku przeprowadzonych pomiarów uzyskano przedziały zmian wartości naprężeń własnych przedstawione na rys. 7. oraz rys. 8. (węższe słupki odzwierciedlają błąd pomiaru - wartości błędu zostały obliczone przez oprogramowanie dyfraktometru Proto iXRD firmy Proto Manufacturing).
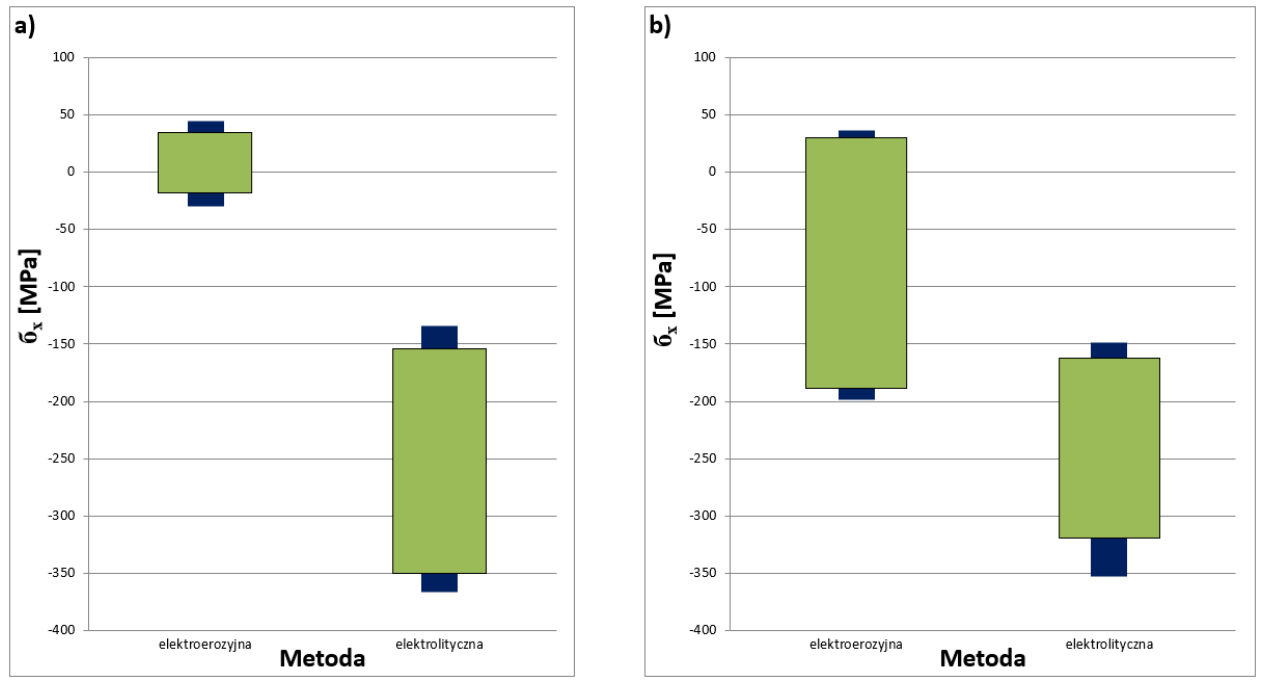

Rys. 7. Wartości naprężeń własnych $\sigma_{x}$ w obszarze podstawy zęba (a) i koła podziałowego (b), w zależności od metody przygotowania próbki
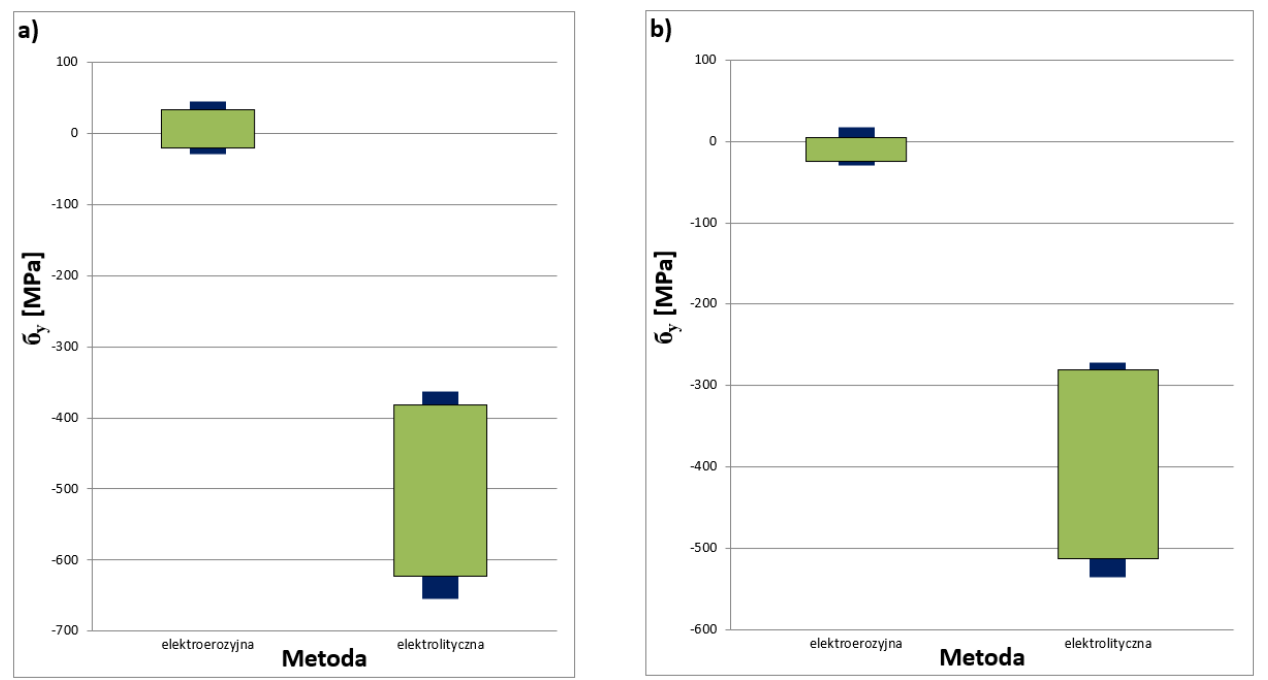

Rys. 8. Wartości naprężeń własnych $\sigma_{y}$ w obszarze podstawy zęba (a) i koła podziałowego (b), w zależności od metody przygotowania próbki 
Na podstawie analizy uzyskanych wyników badań stwierdzono, że metoda przygotowania próbki do przeprowadzenia badań ma duży wpływ na otrzymane w wyniku pomiaru wartości naprężeń własnych występujących w warstwie wierzchniej koła zębatego. Zaobserwowano różnice pomiędzy wielkościami naprężeń własnych próbek, do których przygotowania zastosowano cięcie elektroerozyjne oraz polerowanie elektrochemiczne. Rozbieżności wyników zauważono zarówno w rejonie koła podziałowego, jak i stopy zęba.

Ustalono, że wycięcie zębów metodą elektroerozyjną powoduje odprężanie materiału w wyznaczonych i analizowanych obszarach. Wartości naprężeń własnych wyznaczone na tak przygotowanej próbce są zbliżone do 0 MPa (rys. 7. i 8.). Odległość punktu pomiarowego od strefy cięcia ma wpływ na otrzymywane wartości, co można zaobserwować zwłaszcza w kierunku $\mathrm{X}$ w rejonie koła podziałowego. Zastanawiająca jest różnica uzyskanych wielkości pomiarowych dla tego punktu w badanych kierunkach $\mathrm{X}$ i Y, której przyczyna będzie tematem dalszych badań i analiz. W próbach przygotowanych metodą polerowania elektrolitycznego naprężenia własne w warstwie wierzchniej analizowanych punktów pomiarowych posiadały charakter naprężeń ściskających, oczekiwanych dla rozpatrywanego typu powierzchni, uzyskując wartość do ok. - $600 \mathrm{MPa}$.

W wyniku analizy wyników pomiarów próbek przygotowanych z użyciem polerowania elektrolitycznego zaobserwowano różnice pomiędzy wartościami naprężeń własnych mierzonymi w kierunkach X i Y. W obszarze stopy zęba naprężenia ściskające $\mathrm{w}$ kierunku $\mathrm{Y}$ są większe $\mathrm{w}$ sensie wartości bezwzględnej o ok. $250 \mathrm{MPa}$ w stosunku do wartości naprężeń ściskających zmierzonych w kierunku X w tym obszarze. W obszarze średnicy podziałowej zęba zaobserwowano podobną zależność, przy czym zmiana wartości wynosi ok. $150 \mathrm{MPa}$.

Statystyczną istotność obserwowanych różnic pomiędzy metodami przygotowania próbek potwierdzono, wykorzystując test statystyczny t Studenta (tab. 2.). Wspomniany test t Studenta dla prób niezależnych jest testem parametrycznym i używa się go w celu porównania średnich $\mathrm{z}$ dwóch niezależnych od siebie grup pomiarów. Badane próbki powinny być równoliczne, cechować się rozkładem normalnym i wykazywać się homogenicznością wariancji, jednak niewielkie odstępstwa od przedstawionych założeń nie podważają zasadności stosowania tego testu statystycznego do weryfikacji hipotez.

Przyjęta w badaniach hipoteza zerowa testu t Studenta miała postać H0: wartość średnia naprężeń normalnych $\mathrm{w}$ zadanym kierunku wyznaczonych z użyciem metody elektrolitycznej przygotowania próbek i metody elektroerozyjnej są takie same. Hipoteza alternatywna była formułowana następująco H1: wartość średnia naprężeń normalnych $\mathrm{w}$ zadanym kierunku wyznaczonych z użyciem metody elektrolitycznej przygotowania próbek i metody elektroerozyjnej są różne. 
Tabela 2. Wyniki porównawcze metod przygotowania próbek

\begin{tabular}{|c|c|c|c|c|c|c|c|c|c|}
\hline Obszar & Kierunek & Metoda & $\begin{array}{c}\text { Liczebność } \\
\text { próbki }\end{array}$ & $\begin{array}{c}\text { Wartość } \\
\text { średnia }\end{array}$ & $\begin{array}{l}\text { Odchylenie } \\
\text { standardowe }\end{array}$ & $\begin{array}{c}\text { Bląd } \\
\text { standardowy } \\
\text { wartości średniej }\end{array}$ & Różnica & Przedzial ufności & P-Value \\
\hline \multirow{4}{*}{$\begin{array}{c}\text { średnica } \\
\text { podziałowa }\end{array}$} & \multirow{2}{*}{$\mathrm{x}$} & ELEKTROEROZYJNA & 12 & $-12,2$ & 58 & 17 & \multirow{2}{*}{227,208} & \multirow{2}{*}{$169,706-284,711$} & \multirow{2}{*}{$6,95669 \mathrm{E}-07$} \\
\hline & & ELEKTROLITYCZNA & 8 & $-239,4$ & 59,3 & 21 & & & \\
\hline & \multirow{2}{*}{$\mathrm{Y}$} & ELEKTROEROZYJNA & 12 & $-10,67$ & 8,58 & 2,5 & \multirow{2}{*}{406,333} & \multirow{2}{*}{$339,105-473,562$} & \multirow{2}{*}{$1,95252 \mathrm{E}-06$} \\
\hline & & ELEKTROLITYCZNA & 8 & -417 & 80,1 & 28 & & & \\
\hline \multirow{4}{*}{ stopa zęba } & \multirow{2}{*}{$\mathrm{x}$} & ELEKTROEROZYJNA & 12 & 10,1 & 16,9 & 4,9 & \multirow{2}{*}{232,458} & \multirow{2}{*}{$183,454-281,462$} & \multirow{2}{*}{$9,98734 \mathrm{E}-06$} \\
\hline & & ELEKTROLITYCZNA & 8 & $-222,4$ & 57 & 20 & & & \\
\hline & \multirow[b]{2}{*}{$\mathrm{Y}$} & ELEKTROEROZYJNA & 12 & 9,5 & 14 & 4 & \multirow{2}{*}{536,625} & \multirow{2}{*}{$465,286-605,964$} & \multirow{2}{*}{ 4,02637E- 07} \\
\hline & & ELEKTROLITYCZNA & 8 & $-526,1$ & 83,4 & 29 & & & \\
\hline
\end{tabular}

Jak wynika z tabeli 2., wartości parametru $p$ są mniejsze od standardowo przyjmowanej wartości granicznej 0,05 , czyli $p<0,05$. Zatem można stwierdzić, że przy poziomie istotności 0,05 można odrzucić hipotezę zerową H0 i zaakceptować hipotezę alternatywną H1, co prowadzi do wniosku, iż wyznaczone średnie wykazują istotną statystycznie różnicę między sobą.

\section{Wnioski}

Analiza uzyskanych wyników badań pozwoliła na sformułowanie następujących wniosków:

- Zastosowanie cięcia elektroerozyjnego w celu przygotowania kół zębatych do badań powoduje znaczną relaksację naprężeń własnych, co przy braku doświadczenia $\mathrm{w}$ stosowaniu tej technologii może ostatecznie doprowadzić do błędnych wartości pomiarów, a następnie do błędnej interpretacji wyników.

- Otrzymane wyniki pomiarów oraz przeprowadzone analizy statystyczne dla próbek przygotowanych metodą polerowania elektrolitycznego pozwalają na potwierdzenie prawidłowości wyboru właśnie tej metody przygotowania próbek.

- Przygotowanie próbek z wykorzystaniem polerowania elektrolitycznego pozwala zredukować niekorzystny efekt relaksacji naprężeń oraz zapewnia większą wiarygodność uzyskiwanych wyników pomiarów.

- Wykonane badania pozwalają na rekomendację polerowania elektrolitycznego jako metody, która w znacznie mniejszym stopniu niż metoda elektroerozyjna wpływa na stan naprężeń własnych warstwy wierzchniej, ograniczając tym samym błędy wynikające $\mathrm{z}$ oddziaływania procesu przygotowania próbki do badań.

Wszystkie wyniki pomiarów próbek, do których przygotowania zastosowano metodę polerowania elektrolitycznego, wykazują ujemne wartości pomiarów naprężeń własnych, co świadczy o ich ściskającym charakterze. Porównując otrzymane wartości naprężeń własnych z wielkościami pomiarów kontrolnych przeprowadzonych w obszarach oddalonych od stref trawionych, stwierdzono, że nie występują znaczące różnice pomiędzy otrzymanymi wynikami (otrzymane 
wartości mieściły się w przedziałach ufności), co świadczy o niewielkim wpływie metody polerowania elektrolitycznego na wartości naprężeń własnych i jej przydatności do badań metodą dyfrakcji rentgenowskiej. Przy zastosowaniu metody elektroerozyjnej wartości naprężeń szczątkowych w badanych punktach uległy relaksacji, co może świadczyć co najmniej o niewłaściwych parametrach technologicznych użytych $\mathrm{w}$ procesie cięcia i znaczącym wpływie metody na wartość naprężeń własnych.

W związku z tym, w przypadku występowania czynników uniemożliwiających wykonanie pomiarów naprężeń własnych metodą dyfrakcji rentgenowskiej bez wycinania próbki z badanego przedmiotu, rekomenduje się stosowanie metody trawienia elektrolitycznego. Zaleca się ponadto:

- zabezpieczenie powierzchni niepodlegających badaniu lakierem akrylowym, chroniącym rozpatrywane powierzchnie przed działaniem elektrolitu,

- stosowanie form silikonowych, umożliwiających precyzyjne kierowanie czynnika trawiącego do strefy obróbki.

Przedstawione zalecenia wymagają wprawdzie wykonania dodatkowych operacji, ale w myśl uzyskanych wyników badań są w pełni uzasadnione.

\section{Literatura}

1. Folęga P., Figlus T., Wyznaczanie naprężeń w podstawach zębów kół napędów zębatych, Politechnika Śląska, Gliwice, Journal of Machine Construction and Maintenance. Problemy Eksploatacji (4-2007), s. 83.

2. Kuhn F., Lopenhaus C., Klocke F., Model for the calculation of kinematic roughness in the tooth root, 12th CIRP Conference on Intelligent Computation in Manufacturing Engineering (18-20 July 2018).

3. Freborg A., Ferguson B., Li Z., Modeling Heat Treatment for Characterizing Distortion, Residual Stress, Loading Response and Fracture in a Vacuum Carburized and Gas Quenched Steel Coupon, DANTE Inc., Cleveland, Ohio USA,Thermal Process Modeling, Proceedings from the 5th International Conference on Thermal Process Modeling and Computer Simulation (16-18 June 2014), Gaylord Palms Resort \& Convention Center, Orlando, FL, USA, editors: B.L. Ferguson, R. Goldstein and R. Papp.

4. www.carpentertechnology.com/en/product-solutions/cartech-pyrowear-53-alloy/ (dostęp: 01.04.2020).

5. Kacalak W., Szafraniec F., Charakterystyka topografii stref kontaktu w połączeniach stykowych powierzchni kształtowanych w procesie szlifowania, Mechanik, R. 90, nr 10 (2017), s. 921-923.

6. Jolivet S., Mezghani S., El Mansori M., Vargiolu R., Zahouani H., Experimental study of the contribution of gear tooth finishing processes to friction noise, Tribology International Vol. 115 (2017), s. 70-77.

7. Skrzypek S., Nowe metody pomiaru makronaprężeń własnych materiałów przy zastosowaniu dyfrakcji promieniowania $\mathrm{X} w$ geometrii stałego kąta padania, Wydawnictwo AGH, Kraków 2002. 
8. Krajewska-Śpiewak J., Gawlik J., Wyznaczanie naprężeń własnych za pomocą metody rentgenograficznej w materiałach trudnoskrawalnych, Innowacje w Zarządzaniu i Inżynierii Produkcji, t. 1, red. R. Knosala, Oficyna Wydawnicza Polskiego Towarzystwa Zarządzania Produkcją (2017), s. 783-794.

9. Kocurek P., Nawrocki J., Kubiak K., Sieniawski J., Analiza stanu naprężeń własnych w odlewach segmentu aparatu kierującego turbiny silników lotniczych, Inżynieria Materiałowa, R. 36, nr 3 (2015), s. 129-133.

10. Krupa K., Habrat W., Kocurek P., Sieniawski J., Naprężenia własne w warstwie wierzchniej po toczeniu wykończeniowym stopu tytanu na osnowie fazy międzymetalicznej TiAl $(\gamma)$, Mechanik, R. 86, nr 10 (2016), s. 1508-1509.

11. Gancarczyk K., Kocurek P., Analiza stanu naprężeń własnych i zawartości austenitu szczątkowego w kołach zębatych przekładni lotniczych, Prace XLII Szkoły Inżynierii Materiałowej, Wydawnictwo naukowe AKAPIT, Kraków 2014, s. 172-175.

12. Noyan I.C., Cohen J.B., Residual Stress Measurement by Diffraction and Interpretation, New York: Springer-Verlag 1987.

13. https://wp.kntu.ac.ir/asgari/ (dostęp: 31.06.2020).

14. Fillit R.Y., Perry A.J., Strandberg C., X-ray elastic constants, stress profiling and composition of physically vapor deposited ZrN films, Thin Solid Films, Vol. 197, Iss. 1-2, 10 March 1991, s. 47-55.

15. Fréour S., Lacoste E., François M., Guillén R., Determining Ti-17 $\beta$-Phase SingleCrystal Elasticity Constants through X-Ray Diffraction and Inverse Scale Transition Model, Materials Science Forum (Vol. 681), March 2011, s. 97-102.

16. Mittemeijer E.J., Scardi P., Diffraction Analysis of the Microstructure of Materials, Springer-Verlag Berlin Heidelberg (2004), s. 83. 